\title{
Ethical issues in Finnish-Russian relations: Finnish perspective*
}

\author{
Gennady Polonsky / Erja Turunen ${ }^{* *}$
}

This paper explores the role which western, particularly Finnish companies play in shaping the moral and ethical environment of Russian business. The authors evaluate changes in attitudes and behaviour in Russia, comparing the situation before the introduction of market reform with the developments since. Based on empirical data and interviews conducted in Finland, the authors show that there are at least three groups of problems: Firstly, the low business culture of Russian entrepreneurs, secondly, the question how far Finnish companies can go in adapting themselves to the local conditions, and thirdly, the opportunity of Finnish business with Russia to positively affect the moral aspect of the Russian business environment and to gain knowledge about doing business in Russia.

Der vorliegende Artikel untersucht die Rolle, die westliche (speziell finnische) Firmen bei der Gestaltung des ethischen und moralischen Umfelds des russischen Geschäftslebens spielen. Die Autoren analysieren die Veränderungen von Einstellungen und Verhalten in Rußland, die seit der Einführung marktwirtschaftlicher Strukturen stattgefunden haben. Auf der Grundlage von empirischen Daten und Interviews in verschiedenen finnischen Firmen können die Autoren drei Problemkreise identifizieren: Erstens die geringe Geschäftskultur russischer Unternehmer, zweitens die Frage, wie weit finnische Unternehmen bei der Anpassung an russische Geschäftsbedingungen gehen können, und drittens die Möglichkeiten, die sich aus den Aktivitäten finnischer Firmen ergeben, günstig auf moralische Aspekte des russischen Geschäftslebens einzuwirken und Know-how über das Führen von Geschäften in Rußland zu gewinnen.

Manuscript received: 27.11.1995, revised: 01.07.1996, accepted: 05.08.1996.

** Gennady Polonski, born 1957, Ph.D., Senior Lecture in Economics at the Business School of the Buckinghamshire College of Brunel University, major areas of research interest: Problems of countries in transition, especially the interplay between social, political and economic factors.

Erja Turunen, born 1957, MBA, Vice Principal and Lecture of Human Resources Management and Organisation Studies of Kankaanpaa Business School of Satakunta Polytechnic, major areas of research interest: Learning Organisation in the context of polytechnics (Ph.D. thesis). 


\section{Business ethics: why and how?}

\subsection{Business ethics: a balance between theory and practice}

Business ethics issues have until recently been the domain of philosophers. Business ethics, however, is too important an affair to be left to philosophers (van Luijk 1994). Too little is done to reduce the distance commonly felt between the business world and ethical discourse. It is not difficult to argue that one has to follow ethically acceptable rules and norms. The reasons for ethically acceptable behaviour are also fairly easy to express. How is this applied in practice?

The distance between theory and practice is psychological as well as operational, the latter of which, according to van Luijk, is more important.

People willingly admit that in market operations, in addition to the law, at least the negative moral rule has to be obeyed, i.e. the principle of harm to be avoided. The market itself is supposed to take care of the rest (van Luijk 1994). Ivancevich's views deny any attempts at trying to separate business ethics and the demands of competitiveness stressing that ethics and competitiveness are inseparable (Ivancevich et al. 1994).

According to Cohen (Cohen et al. 1992) there is strong evidence that ethical diversity is related to cultural diversity. Thus the ethical beliefs of Finnish and Russian managers will be different. A Finnish company may attempt to control differences in ethical beliefs and decisions through its organisational culture: this control may be typically exercised through the company's code of ethics. Such a code, and the company's organisational culture, will normally be unitary in nature (Sinclair 1993) and embody deontologically based ethics, reflecting the dominant ethical tradition of Western society and therefore business (Pratt 1991).

To go into depth on the role of culture in ethics is beyond the scope of this paper (see Vitell et al. 1993:773-760). However it is attempted in this study to find out how activities with ethical aspects are conducted in real business world; in Finnish - Russian business relations in this case. How to be moral in the market where the external circumstances including the basic structures of the economy are changing all the time.

\subsection{Law and regulations vs. business ethics}

Ethics is above law. Companies do not operate in a vacuum but within an extensive legal and institutional framework that facilitates or hinders their activity. Within this legal and institutional framework, the state plays an important role as representative of society and the embodiment of authority (Argandona 1994). 
In Russia, the ongoing transformation process has not yet gone far enough; the legal and institutional framework has not been established yet, thus leaving those operating in the Russian market with the feeling of insecurity. This may, in fact, be the decisive factor for many Finnish firms for not entering the Russian market in the near future.

Regulation is a body of general rules or specific actions imposed by the government which interfere directly or indirectly in the business environment (Argandona 1994). Russian firms are in an infant stage; they are learning to operate without government interference. A totally new set of regulations, if there are any, needs to be adopted. As long as the Russian government has not defined the most suitable regulation or decided to abolish all aspects of it regarding business transactions, it can be easily understood that it is the business circles, and individual actors in them, who define those regulations unpredictably, ad hoc.

The absence of a regulation does not, however, justify unethical behaviour. All possible behaviours can never be covered by a regulation. Consequently, above and beyond regulations (and their loopholes) one must observe the rules of ethics.

Another interesting point has been raised by Argandona. Why should a company observe a certain regulation when competitors do not obey it, thus placing the reliable company at a disadvantage? It may even lose competitiveness particularly in certain unethical circles. Perhaps by following Argandona's advice not to take regulations as tedious duties, but as business opportunities, potential dilemmas regarding regulations can be solved (Argandona 1994).

\subsection{Why business ethics in international relations?}

Referring to William A. Evans, we are ready to argue that the morality of the twenty-first century will be based on learning how to live with others. Strong leadership supported by responsible business management will be the prerequisite for the realisation of this morality. Without this, the world may find that the opportunity has passed, never to return (Evans 1982).

It is therefore of paramount importance that the ethical conduct of managers in an international context is taken as a serious issue. It is the people on the international scene, those on the spot, who carry the ultimate responsibility. It is their challenging responsibility to meet people of different backgrounds and to try to understand their culture, history, and values. It is the individual businessmen and businesswomen who make the final judgements when ethical dilemmas emerge in business activities and to do this, they need to realise that ethics is not a game (Evans 1982). 


\section{Finnish business managers and ethics}

\subsection{The changing business environment}

Ethics is a fairly new topic in the discourse of business people in Finland. The past years of recession, the banking crisis, unemployment rates above 20 per cent have led to a dramatic structural and organisational changes in Finnish business life. Mergers, bankruptcies of business firms which were regarded as everlasting institutions caused several shocks in the Finnish business environment and initiated numerous discussions about the future development of Finnish society and the economy. Among them one theme has been consistently repeated and that is business ethics.

\subsection{The managers's ethical perceptions and responsibilities}

Asko Miettinen has conducted a survey among Finnish business managers on their perceptions of ethics, particularly business ethics. The most important stakeholder groups in the ethical perspective have been identified. Customers ranked first, personnel and owners came in second and third (see table below) The table contains a comparison between the years 1981 and 1992.

Table 1: The importance of stakeholder groups as perceived by Finnish business managers (Miettinen in Luotonen 1994:48).

\begin{tabular}{|lcc|}
\hline & \multicolumn{2}{c|}{ Average* $^{*}$} \\
Customers & 1981 & 1992 \\
Personnel & 1.72 & 1.32 \\
Owners & 2.52 & 2.61 \\
Financiers & 3.26 & 2.88 \\
Suppliers & 4.15 & 4.36 \\
State/government & 4.59 & 4.55 \\
Municipality/town & 5.71 & 5.94 \\
& 5.86 & 6.13 \\
*1 = most important. 7 = least important. & & \\
\hline
\end{tabular}

Finnish business managers regard customers as the number one stakeholder. However, the most unethical practices that these managers had encountered had to do with competitors. Conflicts with customers and personnel were the second most frequent (Miettinen in Luotonen 1994:48).

In which areas do those interviewed feel that ethical issues demand greater attention? 39 percent of the Finnish business managers regarded marketing as the most questionable function. As many as $60 \%$ of the business managers felt 
that misleading advertising should be eliminated from business life. Another area where Finnish managers felt strongly was environmental issues.

In twelve years, moral perceptions have changed surprisingly little. A Finnish manager relies on his own beliefs, subjective considerations of right or wrong. The type or the size of business does not play any role in this. Sex does, however; female managers tend to be morally more sensitive and their requirements for business practices tend to be higher (Miettinen in Luotonen 1994:48). Women expressed more criticism towards the impact on the ethical level of business, of business organisations, the media and legal regulations.

All stakeholder relations include ethical issues considered by managers (Laurila 1993). Laurila suggests that stakeholder theory could help us to analyse and understand moral and ethical problems in business. The moral muteness of managers discussed by Bird and Waters has been observed by Laurila as well. „Although the managers interviewed did not always refer to these problems as ethical or moral, the business ethics literature clearly indicates them to be so. It seems that managers sometimes lack the ability to discuss things in ethical terms, but this does not necessarily mean that they are ignorant of these issues“ (Laurila 1993:10).

\subsection{The ethical responsibilities of a firm and of a manager}

Ethical responsibilities are responsibilities that are expected - not so much desired, as required - by stakeholders. According to Carroll (1989), ethical responsibilities consist of:

1. avoiding questionable practices

2. responding to the spirit of the law

3. assuming that law is the minimum ethical basis for behaviour

4. operating above the minimum required by the law

5. asserting ethical leadership.

Laurila discovered that the following ethical issues are involved in stakeholder relations (Laurila 1993:9).

- stakeholder

- customers

- employees

\author{
ethical responsibilities \\ honesty \\ product quality \\ good working conditions \\ stability and security \\ development possibilities \\ honesty \\ education
}


- competitors

- owners

- suppliers

- community and government

- financiers

- environment truthful information

fair marketing and pricing practices

no use of questionable practices

consistency and stability

playing the game by its rules

adequate information

honesty

behaving with integrity

adequate information

environmental friendliness

protecting the environment

product recycling

A manager with a sustainable ethical basis has been characterised by Hämäläinen as follows (Hämäläinen 1993:61):

a realist; decisions and actions are based on facts. A manager must face the facts.

ethical; co-operation is based on trust. Receiving is based on giving. A manager is human.

brave; a manager is always ready to start something new. New activities demands courage to rise above the ordinary solutions. A qualified manager has the energy to renew himself/herself.

$a$ visionist; a successful manager can see far into the future. Vision equals strength and vision gives strength. Everyone in the organisation must believe in the future, together.

Every manager can develop his/her ethical principles and behaviour. Hämäläinen gives the following advice (Hämäläinen 1993:61)

1. Be an example; show that you are loyal to your organisation and to your colleagues.

2. Express your basic values to others. Behave accordingly.

3. Keep your promises and commitments

4. Show that you are genuinely interested in the welfare of others.

5. Concentrate on developing positive human relations.

6. Speak in a manner that shows you understand the points of view of others and that you respect others as individuals. 


\section{Studying Finno-Russian business relations}

\subsection{The scope of the study: SMEs in the North-Western part of Russia}

Small and medium-sized businesses are often left out of the scope of research. Yet, business with one particular country, Russia in this case, may account for up to 80-90 percent of a firm's total sales. Satakunta, a province situated on the Finnish West coast, is known for entrepreneurship, as well as for its large enterprises in the metal paper and pulp industries.

Now that the Russian market is offering new challenges, many small firms have began to operate in the East, i.e. across the Eastern border of the city and the surrounding area of St.Petersburg.

\subsection{The significance of North-Western Russia for Finland and her economy}

Together with Stockholm and Tallinn, St.Petersburg, with over 7 million inhabitants - some 10 million if the surrounding regions are included - forms the closest center of international business operations for thousands of Finnish business firms. The potential is there, the market is there; yet, the firms actually operating in Finnish - Russian business are counted in hundreds rather than thousands.

Finns do enjoy - it is often argued - many advantages in doing business in Russia and with the Russians, compared with firms (and people) from other Western countries.

According to a survey conducted by The Finnish Delegation of Business Life (EVA), the Finns have more basic knowledge, more information and a better orientation ability in operative matters when dealing with Russian business partners and operating in the market (EVA 1992:88). If this is true, shouldn't Finnish companies be in the forefront as the Russian economy moves towards market-oriented thinking and behaviour?

In our opinion, Finnish firms and Finns as natural business partners could help Russian partners in moving towards business conduct and behaviour based on principles of honesty, trust and ethical soundness. That is, they could help in establishing business relations that can serve as examples for others, too, where both parties are satisfied in the long run.

The status of Finland in the European context has changed. As a member of the European Union, Finland has a new position on the world map; her Eastern border is the Eastern border of the EU. Each member country naturally brings its national characteristics to a joint European co-operation. What is expected of Finland, in addition to the Nordic democratic values, is wide and versatile knowledge of Russia (Forsman 1995)? Does Finland possess this expertise? How is it valued in the wider European or international context? 
From the point of view of developing business relations with Russia, it is essential that Finnish and Russian business people think of each other as equal partners. What is the attitude towards Russians among Finns? How do Russian business people perceive Finns as business partners? What is the level of trust between the individuals. It is important to remember that organisations never close business contracts, it's always the individuals who do it.

The North-Western regions of Russia (St.Petersburg, Karelia, Murmansk) will develop as the whole country of Russia develops. Various scenarios have been considered.

There are two possible scenarios for of St.Petersburg; a Russian version of the Japanese model or the authoritarian bazaar economy of Latin America (Varila 1992). The first will have its basis in Russian economic culture whereas the second would be a compromise between market economy and centrally planned economy. The first is considered as more likely.

Another perspective is the strengthening of St.Petersburg within Russia: economic activity will gravitate there, i.e. within the Finnish sphere of influence. As economic activity concentrates in St.Petersburg, strong repercussions for the Finnish economy can be expected. As Blom says, (Blom 1992:4) „St.Petersburg may have as great an impact on Finnish life-style as the European Union at the end of the 1990s“.

The future of the Republic of Karelia will depend more on internal than external factors (Liuhto 1993) of which the trade between Karelia and Finland is seen as the most significant (Remes 1992). As far as Murmansk economic region is concerned, the future will greatly depend on the possibilities of utilizing its existing natural resources. As a conclusion of its report on the Finnish - Russian business environment and business relations, EVA states the significance of St.Petersburg in three aspects:

1. St.Petersburg is a gateway to the Republic of Karelia and even further to Murmansk and Kola - all important nearby regions for Finland. The developments of the metropolitan area of St.Petersburg can first be felt in Eastern and South Eastern parts of Finland. Towns such as Lappeenranta, Imatra, Hamina and Kotka, home firms in a key position when dealing with foreign firms wishing to get established in St.Petersburg. Although the infrastructure is not yet there, Finnish firms could help to overcome this problem.

2. It is not necessarily easy for Finnish firms to operate actively in the vast country of Russia, in new and unstable circumstances. The administrative and political centre, Moscow, must be closely observed at all times. It is only realistic to assume that St.Petersburg will be the business target and the market place in Russia for Finland for a long time. The impact of St.Petersburg on Finland is expected to increase. 
3. St.Petersburg can also be seen as a means by which the Finns can observe the developments of Russia.

\subsection{Finno-Russian business relations: what do we know by now?}

\subsubsection{Joint Ventures}

The operational options for business activities with Russia are the same as anywhere else: from small-scale exporting or importing to fully owned production facilities in the country.

Some Finnish firms have been partners in joint ventures with Russia (USSR) since the early 1970s and therefore Finns may be expected to have some competitive advantage in terms of the know-how and management expertise required to operate such an enterprise. The managerial challenges are there: have the Finns succeeded in business management in joint ventures?

Liuhto addresses the question of business management in his report „The Way to Success in the Near-by Regions of Russia“ in 1993. Through empirical research he attempts to highlight „the everyday realism“ (Liuhto 1993:3) of the strategic and the operational management of joint ventures.

In order to be successful in the North Western regions of Russia. Finnish firms should establish themselves in these regions very quickly. Only through operating locally can, a business firm react rapidly enough to the opportunities offered by the market (Liuhto 1993).

Local operation is a basis for, not a key to, success. In addition, capabilities, know-how, and practices suited to the present requirements of the market are needed. A sufficient „Eastern capability“ is a prerequisite; whatever is lacking, should be compensated for by other means or measures. The list offered by Liuhto could serve as a guideline (Liuhto 1993:60):

prerequisites

experience from Russian market

sufficient economic resources

possibilities to wait for profits

reduction of cost level

knowledge of local area channels

flexible and rapid action

ability to function in uncertain conditions

ability to function in Russian bureaucracy

Russian language skills measure/activity

choice of right partner

co-operation with Western firms

compensatory trade arrangements

local materials and personnel

build-up of reliable information

local unit

contingency planning

local assistants

e.g. hiring Estonian personnel

In his earlier qualitative organisational cultural analysis of three Finnish - Soviet joint ventures, Liuhto came to the conclusion that the managerial culture of joint 
ventures was largely dominated by the Russian managerial culture rather than the Finnish managerial culture. In terms of Hofstede's cultural dimensions, Liuhto described the Russian - Finnish joint ventures as follows (Liuhto 1991:100):

- a high level of power distance; which is lower than in traditional Soviet companies due to the reflection of Finnish managerial attitudes in joint venture operation;

- a high level of uncertainty avoidance; Finnish management has been incapable of influencing the dimension of uncertainty avoidance as strongly as the power distance dimension;

- a medium level of individualism; Finnish individualistic features have positively affected the behaviour of joint ventures' personnel and their staff can thus be considered as having a higher degree of spontaneity than staff in Soviet companies;

- a high level of masculinity; the Finnish influence on masculine managerial behaviour is fairly weak. The attitudes (and thus the behaviour) of the Finnish managers have become more masculine traditionally because of the preference of the Soviet market of masculine managerial style.

Liuhto concludes from the examination of the joint ventures interviewed that the steps those firms have taken towards the integration of managerial cultures have been incoherent and often lacking in planning. The need for this kind of integration has been recognised, however, only a few joint ventures have actually taken steps in order to unite the managerial cultures (Liuhto 1991).

Considering our task, it is interesting to see how the Finnish partners see the situation now - after the dramatic change in the external economic system. Has the new ideology been transferred to the managerial level; if yes, how does it show in the business relations of joint venture partners? Training, communication, personnel management as a whole; they all are areas through which the integration of managerial cultures can slowly happen. We will come back to this issue in our case study.

\subsubsection{Subcontracting in Russia}

The Finnish textile, clothing and shoe industries in particular have moved a bulk of their production across the national border: Southwards to Estonia or eastward to Russia. Portugal and Poland as traditional contract manufacturing partners have gradually lost their position; particularly as Portuguese cost levels have risen to the point where the profitability of subcontracting is no longer valid (Erkintalo 1994).

The bulk of Reima-Tutta products are being sewn in Estonia, China and Russia, mainly. The final production phases are always carried out in the Finnish 
facilities, „to guarantee high quality“. Reima-Tutta Oy is not going to move all of its production abroad. „We are so strongly established here in our own region“, says Mauri Paukkunen, Administrative Manager of Reima-Tutta Oy. Finland's decision to join the EU is one of the reasons for strong domestic production.

Some Finnish textile and clothing companies have allowed the final production stage to be carried out in Russia, Luhta Oy, for example. „, We are satisfied with the quality of work“, said Pekka Luhtanen of Luhta Oy.

\subsubsection{Exports}

Exports will remain the main mode of operation in the neighbouring market, probably for a long time. To share costs as well as to reduce other than purely economic risks, some manufacturers, whose products neatly complement each other have created co-operative networks for operating in Russia. In Finland, these firms are usually helped out by the Finnish Foreign Trade Association. Its Lappeenranta office on the Eastern border of the country is specialised in EastWest trade issues.

\section{Business ethics and the transition in Russia}

\subsection{The legacy of the past}

The euphoria of the first years of perestroika and the naive belief that the transition of the centrally planned economy to a market economy could take place during a short period of time have evaporated. The legacy of more than seventy years of the Soviet economic strategy, together with serious mistakes made during the years of socio-economic and political transformation, brought the country to the edge of collapse.

Unprecedented in human history, Russia has to cope with not one but with three transformations at the same time: transformation from dictatorship to democracy, from empire to nation and from economic breakdown to revitalisation and growth (Sachs 1994).

It is no longer questioned that simple dismantling of centrally planned institutions doesn't make a market economy. The problem was „that many of the needed preconditions for successful economic reform were missing. Nor did they emerge quickly, spontaneously, or cheaply“ (Lapidus 1995). A special set of institutional arrangements is required for a market economy and among the most important ones is a developed legal infrastructure to protect private property and the individual as well as society as a whole.

Economic freedom without strict boundaries of law can lead to chaos, crime, anarchy and violence. At the same time the legal aspect is never in itself 
sufficient. There can always be cases where laws and regulations are inadequate (Clark / Lattal 1993). An internal ethical and moral code is needed.

The development of the institutional arrangement of the Russian market economy should not and cannot be separated from the development of the language of trust - business ethics. The importance of the role of business ethics in long-lasting economic prosperity is increasingly recognised by Western and Russian economists.

To understand the current state of the business ethics in Russia and its role in shaping the Russian economic environment, one has to look at the history and the factors which influenced the philosophy of economic behaviour.

Although formation of entrepreneurial ethics is historically a lengthy process which can be traced back thousands of years in Russian history, we believe that the development after the revolution of 1917 influenced the current economic behaviour the most.

The revolutionary and later the pseudo-revolutionary morality of the Soviet system according to which an aim could justify any means, ,double thinking“(one for party meetings and public gatherings and another for oneself), the atmosphere of paranoia and spyomania, when people often wouldn't even trust their closest friends and families, couldn't but seriously damage the morality of society, in general and business ethics in particular.

Trust is needed for effective business co-operation. It can also greatly reduce cost of doing business. According to the results of the project analysis of factors which make international joint-ventures between Russia and foreign countries successful, mutual trust and ethical behaviour are named as the most important ones (Fey 1994).

We fully agree with Clark and Lattal that the marketplace is becoming more hospitable to ethics and there is a close connection between ethical behaviour and profit. „On the one hand, ethical companies avoid the negative consequences of unethical behaviour, such as bad publicity, fines, and the legal expenses of defending themselves in the court. On the other hand, they acquire all the benefits of a good reputation: loyal employees and business associates, easier recruitment of the most talented people, a stronger spirit of teamwork across all employee levels, higher morale, both new and old customers who are attracted to what the company stands for, suppliers who are more accommodating and reliable, goodwill from communities in which companies operate.“(Clark / Lattal 1993:2)

However it is also true that „someone who behaves more ethically simply to increase profits has failed to grasp what morality is all about. Ethical values are the highest of all values, which means that being moral for the sake of profit undermines the very idea of morality ... ethical actions have payoffs that 
transcend business ... As far as the profit motive is concerned ... being moral usually is the most profitable course of action. However, there is no guarantee that it will be“ (Clark / Lattal 1993:3).

\subsection{Current problems regarding business ethics}

In Russia, partly due to the unstable socio-economic and political environment, in which most people have one aim and that is to survive, and partly due to the legacy of the communist past, low trust attitude dominates the business environment. „Not only did Stalinist thinking itself involve a suspicious attitude to others, but the increased absurdities of over-centralised planning led to a general distrust of promises made by anyone working within the economic system. This atmosphere of distrust was exacerbated by the widespread use of informers reporting to the secret police“ (Casson 1994:46).

For more than seventy years antipathy to entrepreneurial activity was persistently cultivated by communist bureaucrats. Until 1991, entrepreneurial activity was illegal and entrepreneurs prosecuted.

Stalin's view that the Politburo and planning bureaucracy should maintain control over management and workers who could not be trusted to comply with the wishes of authorities was dominant in Russia (Angressano 1992).

The tough school of the centrally planned economy brought its negative fruits in the form of an army of generally well educated managers who lacked the qualities necessary for running an enterprise under market conditions. The area of least knowledge seems to be in managerial ethical and social responsibilities (Edwards 1994, Polonsky 1994). Under the communist system in the Workers' State managers were supposed to have a great concern for their workers and all of them had to have a well-developed sense of responsibility to society, possibly through attending numerous courses in Marxist-Leninist ideology.

Soft budget constraint and its politics also contributed to the erosion of business ethics (Kornai 1992). The cultural legacy of Marxism could be a major handicap in the newly liberalised economies (Etzioni 1991).

The above mentioned observations are mostly true for the older generation of managers who were educated under the communist system. At the same time, there is a new generation of managers who developed their values during perestroika and the years of transformation. They are much more independent and entrepreneurial in their behaviour.

The collapse of the economic and political systems in Russia shattered the fragile remains of old communist values. Parting with the socialist idea of equality and giving up personal security for the unclear benefits of market competition have brought fear and anxiety to many people. 
Struggling with the still existing and active state bureaucracy in the low-trust atmosphere of the economic system and being afraid of finding themselves on the dark side of the market have made some people think that all means are justifiable as long as they help them to survive and prosper. There have been numerous cases where managers were deliberately running down their enterprises in order to buy them cheaply on privatisation (Novacek 1991). This attitude is often stimulated by the gaps in government legislation and numerous cases of corruption among government authorities. In a way the level of managerial ethics of some new entrepreneurs can be compared with that of the First Industrial revolution. In the constantly changing legal and economic environment, they often find themselves surrounded by the perverse commercial behaviour, a corrupt public sector, illegal trading and general absence of any kind of business ethics and morality. To quote Oscar Wilde, they know the price of everything and the value of nothing.

Some of the successful entrepreneurs who very often set the standards of business behaviour developed their own business experience while working in the black market economy with its dog eat dog ethic.

Another strata of businessmen came from the old party nomenclatura, who enjoyed high positions under the old regime. They have the money, property and numerous connections, „the old boys network“; which help them to get the cream of small privatisation and acquire large proportions of shares of in the large privatised State enterprises.

The speed at which old party apparatchics turned into businessmen confirms once more their cynicism and disbelief in what they were preaching for most of their lives. According to some estimations, from 30-40 \% of the capital used during privatisation in Russia was communist in origin (Bovin 1992).

The report prepared by the Institute of Social-political Studies at the Russian Academy of Science states that the rapid transformation into rich and poor will foster a wide-spread negative attitude towards high income groups. The view that the primary way to become rich is to be engaged in an activity which runs counter to the law and morality has become the steadfast opinion (Ivanov 1995). The report states that very often the ,government course of developing private entrepreneurship does not include preventative measures to control economic crimes nor the negative social consequences that accompany this development. Among the most dangerous violations are the collusion of rivals to keep prices at the same level, as well as activity that is hazardous to health and environment“ (Ivanov 1995:34).

However, what is even more frightening is the growing belief that business is amoral, that it has to follow its own very often unethical but necessary rules. According to a recent survey made in the second biggest Russian city, those of the interviewed are sure that it pays to cheat (St.Petersburg novosty 1994). 
The turmoil in Russian economic life made the difference between entrepreneurship and the Mafia almost disappear. Big and growing criminal groups exercise increasing control over the Russian economy, dividing the country according to their areas of influence. They almost openly exist in the financial sector, international trade, transport, and property market. According to Yuri Baturin, the Russian President's advisor, the core of the Mafia in Russia consists of 25,000 people. They control more than 40,000 commercial enterprises, of which 400 are banks, 47 stock exchanges, and 1,500 are stateowned firms. Mr. Baturin estimated that corrupt government officials assisted at least a quarter of Russia's criminal gangs (Freeland 1995). According to another estimation more than a third of profit generated goes for bribing of government officials (Nedela 1995). Criminality is now one of the obstacles in the way of developing Russian business and the business environment there. Entrepreneurship becomes a very dangerous job. During only two years (19941995), six hundred entrepreneurs and thirty six directors of Russian banks were murdered, and seven hundred companies' offices were blown up (Nedela 1995).

„One cannot be taught good table manners on the dirty table linen“, a Russian humanist, A. Makharenko, observed once. So is it realistic to expect companies with high moral and ethical standards to survive and prosper in such an environment, especially if the company is foreign and the cultural and economic differences between the countries are great?

\section{Methodology}

\subsection{Data collecting and analysis}

Our approach is eclectic in that it seeks to relate macro issues, such as the institutional context, to the behaviour of individual entrepreneurs. It thus draws on a range of primary and secondary sources.

However, while quantitative data can provide a sense of general trends, a case study approach enables the researchers to gain greater understanding of pertinent issues at the level of individual firms (Bridgewater et al. 1993). Data for the case study was collected by means of semi-structured interviews with eight company managers and analysed using content analysis (Holsti 1969).

The aim of the study is to evaluate opinion espoused by the managers of some Finnish companies. The actual practice of the companies working in Russia will be the focus of the next research.

A number of top and middle managers of four Finnish business firms with business activities in Russia were interviewed in January-February 1995. The length of the interviews ranged from one and a half to two and a half hours, with an average length of one hour and forty minutes. 
The interviews were tape-recorded and typed out afterwards.

The method of qualitative interviewing is felt to have been proven as a firm instrument for gathering the relevant information. The empirical evidence uncovered preconceptions on behalf of the researchers, conveyed deeper insights into the research problem, pointed out the further research direction, and revealed the issues that interviewees are prepared to reflect and report on.

The four firms represented here are small by any international standards, but most of them are domestic leaders in their own field and highly appreciated for their quality and entrepreneurship. Some have already won a good international reputation and successfully operated in foreign markets for almost twenty years. Some are only in the starting stage of international operations.

All the firms are located in the Northern part of the province of Satakunta, near the Western coast of Finland. The distance from these firms to the Eastern border between Finland and Russia varies between 400-500 kilometers.

The four Finnish companies mentioned above formed a network and opened up a joint sales office in St. Petersburg, named Quartet Group Ltd.

\subsection{Case: Quartet Group Ltd. introduced}

Quartet Group Ltd. - consisting of four small and medium-sized companies in labor-intensive shoe manufacturing and textile and clothing industries, the group represents a combined experience of 60 years in Finnish - Russian/Soviet business. The managers interviewed have all personally run East-West trade for years, three out of four during ,the old system” as well as today. Thus, these managers can be regarded as experts in the field. The shortest experience has been gathered by Kassimatti Oy; they set up a joint venture in Russia only four years ago.

The Quartet group was established, in the first place, to boost exports to Russia; to find the right distribution channels and to operate in the market and to be where your customers are (Fonsen 1995). Four Finnish companies operating in the labor-intensive shoe, textile and clothing industries opened up a joint sales office in St. Petersburg in April 1994, thus expressing their intention to stay on the market long-term.

\section{Ethical issues in Finnish-Russian business relations: How Finns deal with these issues}

\subsection{Who is your business partner?}

According to Miettinen (1994), Finnish managers regard customers as the most important stakeholder group. That is why it is the Russian business partners who purchase and buy Finnish products who are discussed here first. 
One of the biggest problems in practical business operations that the Finns have encountered is finding customers knowledgeable enough and interested in creating long-standing business relations with their foreign partners. It would be easy to operate on a day-to-day basis; sell whatever the customers wish to buy and try to make the most out of it, in terms of profit. As for Russian customers, this attitude would suit some of them, as well. The hit and run philosophy can be justified in an unstable environment.

The purchasing culture has changed completely from the years of bilateral trade and the five-year agreements characteristic of Finnish-Russian trade until 1992. As the quotas were given, the only issue discussed in the business negotiations was the price. The buyers during the old system were skilled and knowledgeable people who knew the products; it was their task to find the Finnish products that would meet the prevailing standards in terms of quality and then bargain for the lowest price. Getting such a contract would, and this is not an unusual circumstance, mean that a Finnish partner was guaranteed business for years to come.

„In those days you could not even think about your distribution policies, let alone marketing as we understand it. All you could do was to come down with your price as much as you could. “

How to identify your customer now when the entrepreneurship flourishes and almost anyone is willing to buy your products. The wholesaling level has disappeared from the distribution channels; it is the active individuals who buy and sell. It is clear that the business culture has not been established, which gives opportunities for misconduct in the market.

This instability in business relations, i.e. the fact that you don't know who you are dealing with, has led to the development of a common practice amongst Finnish exporters to Russia whereby the only form of payment in business contracts is advance payment. „The goods do not cross the border before we have the money. It is as simple as that", explains one of the interviewees with a considerable experience in East-West trade.

\subsection{Customers and quality issues}

The Russian consumers, the minority of which have enough money to buy Western-made goods, want high-quality products and prefer well-known brands. For a deal to become a good business for the Russian importer, he should be able to sell the imported lot easily and at a high enough profit. Do they know what is or will be good business? Is it the duty of the (Finnish) exporter to help in deciding that and guiding the purchasing operations to some extent?

The Finnish exporters would, in the view of Quartet Group Ltd., be morally right if they refused to sell the Russian business partners products which they 
know are not suitable for the end consumers. This is how Top-Knit Oy has approached the problem:

„When someone wants to purchase products of our selection which we think would not be successful in the Russian market, we kindly refuse to sell them. Rather, we advise them to choose those products which we already have experience of in this particular market or which we otherwise place in the proper category."

How often does the seller think in these terms? Certainly there are too many Finnish businessmen operating in the Russian market who try to get the most out of the situation, in the short run. The managers interviewed all supported our view that after being unsuccessful in the domestic market, many companies enter Russia in reach of fast remedies for their economic crisis. Some do it in Estonia first, and, after finding problems there, continue in the St. Petersburg area.

The quality of the products sold to Russia is an ethically sensitive question. The exported products to Russia today need to fulfil the highest quality demands. They fall into the highest price category in Russia with the result that only the richest segment of the population - approximately 5 percent in St. Petersburg, according to the managers interviewed - can afford to buy the Finnish-made goods. Any low-price Finnish goods would be far too expensive for the vast majority of Russians, so the export interests of the Finnish producers of consumer goods have in the past few years centered around high-quality (design) goods. The bag manufacturer of medium-priced products like backbags and sports bags, describes his situation:

„We can't see we'll export there in the near future. An average Russian cannot spend $20-30 \%$ of his/her monthly earnings on an ordinary backbag. We are far from the masses. "

That's why the company has decided to concentrate on manufacturing in Russia; the products are imported to Finland and sold in Scandinavia.

It could also be easy in Russia, due to the economic circumstances there, to market products made of materials of lower quality than elsewhere, but using the same brand name, for example. Practices certainly vary among Finnish business firms. Our case company, Top-Knit Oy, has taken the following stand:

„We have a clear policy as far as materials are concerned. We don't offer our Russian partners any products made of artificial fibres; it is all 100 percent wool."

\subsection{Creating long-term seller-buyer relations}

To create long-standing business relations from a Finnish point of view requires systematic input and interest to do so. Quartet Group Ltd. emphasises the 
importance of good personal relations in business, as well as the responsibility of the exporters to create a modern purchasing culture.

This is best achieved, in their view, by introducing the buyers to the production and quality culture developed in Finland. By inviting their partners to company visits, and showing them how the products are made, the materials chosen and handled, etc, the Finnish textile, clothing and shoe manufacturers believe they can help in developing circumstances for fruitful co-operation that lasts longer than one or two deliveries. It cannot be assumed, they feel, that the new Russian business generation are experts in their fields; they need to become such, however, in order to develop flourishing business for both parties.

It would be unfair to state that those involved in purchasing operations in Russia were not capable of deciding what is best for them. The young business people in particular have adopted the Western way of business very quickly.

„Some have a suprisingly clear picture of what market economy is all about. The minds of the new generation are not loaded with the tape-recordings of what the world (market economy) should be, like ours are. They may have a very fresh image of how things can be done."

\subsection{How do you treat your workers?}

The second most important stakeholder group for Finnish business managers are the employees (Miettinen 1994). What kind of ethically significant considerations are there involved in the relations between the Russian employees and the Finnish joint venture partner who is normally the majority owner of the venture?

On average working moral of Russian employees, as well as their commitment to the company were observed by Liuhto (1993) to be fairly low. Companies had faced thefts, some employees may have run their own business in working hours, absenteeism was a problem, and drinking at work was common.

The members of the Quartet Group approach the employer-employee relationship on the basis that the social security system in Russia is far behind that in Finland or other Western European countries. The job is their social security. In the joint venture where Kassimatti Oy and Dynamo of Russia are the two partners, the best workers have been chosen to work in the joint venture. A similar production with a different product line still goes on in the traditional part of Dynamo, in the same facility. The Russian employees see joint ventures as an opportunity to enhance their standard of living. The Quartet Group believes, this is because the joint venture pays them better. Perhaps more importantly, they get paid on the day they are supposed to. It is the problem of non-payment of salaries that has raised upheaval in many branches of the Russian economy, as we have observed lately. 
The Finnish firms are fairly satisfied with the quality of work in Russian textile and clothing joint ventures. „In order not to offend our Finnish employees, I must say they are equal." The quality has not been a problem in the bag manufacturing joint venture. Instead, some textile firms carry out final production in Finland - this is the practice of Reima-Tutta Oy, for example.

The working culture is changing. It seems that with a fair attitude towards the employees it is possible to raise the motivation and commitment level. „I don't stand and watch my workers do their job in Finland, either", claims a Finnish manager who has trusted the management of his firm's joint venture to a Russian manager from the very beginning.

\subsection{Managing the Joint Venture}

\subsubsection{Where do ethics come in?}

There are at least two aspects of management of joint ventures that require attention with regard to business ethics.

The first is: to what extent does the foreign partner trust the management (decisions, operations) to a local manager? What kind of role does the Finnish partner take in facing managerial culture different from his/her own?

The second issue is the question of repatriation of profits. What are the benefits of bringing the money back home compared to the situation where it is left abroad and used in investments or for other purposes there?

Our case company illustrates an approach which might serve as an ethically acceptable way to relate to Russian management of joint ventures. Please note the discussion here is limited to only the two aspects mentioned above.

\subsubsection{The managerial culture}

As in the case of employees, the managers of joint ventures get better pay than managers of Russian firms, generally. They have much better access to modern technology, to modern communication as well as to managerial training than their colleagues in Russian firms. This could be a base, we think, for a new managerial culture.

As suggested earlier, the Russian managerial culture traditionally lacks in cooperation and is more power-concerned than the Finnish managerial culture (Liuhto 1991). The Finns feel they have the right to, even the responsibility of integrating these cultures to the extent where major differences would not disturb the practical operations of the firm.

Training and education are seen as the number one means of integrating managerial thinking and behaviour. The Western investor wants to make sure that the capital invested is taken good care of; what is perceived as lacking is 
taught to the Russian partner through a lengthy training period in Finland and thereafter under the guidance of a Finnish manager in the Russian manufacturing facility.

A remarkable unanimity prevails among the Quartet Group members about the role of the Finnish partners in production co-operation in Russia - be it a joint venture or other type of industrial co-operation. Namely, they see themselves as the providers of know-how and new technology, which manifests the attitude they would like to call the „educators' attitude“. Without this attitude, they believe, co-operation would not be as smooth and successful as it is now.

Admitting that the main reason for starting production in Russia is the low level of costs there, the Finnish managers see joint ventures as a desirable way of relatively rapidly increasing the managerial skills and changing the managerial culture which will, consequently, contribute to the development of the wider business culture of Russia.

„The respect for work (which was seriously damaged during the communist years - G.P. / E.T.) is a major challenge for Russian (political) leaders. The ideological gap is vast. Also the managers of Russian business firms must understand their responsibility for the firms success. They have to educate themselves as well as to motivate their personnel. “

\subsubsection{Profits: repatriation or not?}

The second issue in management with ethical considerations raised here is the question of capital repatriation and its legitimacy. For Russian society, a big problem is the fact that Russian capital is not invested in Russia but escapes abroad (Hultin 1995). Should it be the responsibility of joint ventures and other forms of foreign investment to keep the investment level at a somewhat bearable level?

In our case study, we discovered an attitude worth considering from an ethical perspective.

The basis for successful business operations is laid at home: before one enters the Russian market, the domestic market should be in good condition. Russian operations should not be expected to bring about great profits rapidly. Business with Russia is a long-term effort where the foundations must be laid thoroughly and carefully. Finding the right partner is one of the key issues for success, as was discussed earlier.

The message gathered from the case organisations can't be interpreted other than in the following way: When you start making profits from your operations in Russia, you are better-off leaving the money in the country as an investment in more up-to-date technology, or more importantly, in improvements to the business surroundings and the job environment of your partner company. By investing in the environment of your joint venture you can improve the social 
conditions of your employees remarkably, thus increasing the morale of the workforce.

A spin-off effect is bound to result from „such good deeds“. After all, as our manufacturing joint venture exemplifies, the sums one might be able to bring home are worth much less on the Finnish side of the border than in the East. With a hundred thousand marks, for example, the housing of the workers can be improved or playgrounds for children built. Once again, the job is the social security of the employees.

The impact of this kind of activity could be the key to a modern working culture, and a managerial culture closer to that of the Western partners as well as the business culture with less moral conflicts than today.

\section{Business ethics in relation to Russians as business partners}

\subsection{The historical burdens}

The Finns have been accused of having a superior attitude when travelling to Russia. Also, the EVA survey conducted in St. Petersburg among business people there indicates similar behaviour when in contact with Finnish business partners (EVA 1992). The Quartet Group members, when asked if this perception is justified, agreed that the past history and the models of cooperation learnt during the Soviet Era still prevail among many Finnish people.

„We as businessmen have a lot to do there ... to change this perception.“

The attitude towards business partners largely affects one's behaviour in conducting business. The attitude held by the majority of Finns who experienced the years of two wars with Russia is crystallised in an old saying: „A Russian is a Russian, even if you bake him in butter.“ This attitude has changed during the post-war years. Personal contacts play a crucial role in this.

„Having had business contacts with Russians during the past five years, I had to change my views on them ", one of the managers admits.

\subsubsection{Different histories - different motives}

Finns seem to find two categories of business people in Russia.

"I can see it very clearly that there are two groups; the first is those who get along by the hook or by crook, the second is matter-of-fact, businesslike."

Another categorisation is offered by Tom Hultin, a Finnish consultant operating in St. Petersburg: „It is a world of its own. The old Soviet system still prevails. The men of former power still try to guard their own playground“ (Hultin 1995). One of the managers interviewed describes the division of Russian business people into the „old-timers” and the new generation as follows: 
"We have a long-time business partner who acts like during the old command economy. They talk big, negotiate, eat and drink, live the pre-perestroika time. Those people still have not entered the change process.

The second group is new and rising. They are usually in their mid-thirties and they think very much like Western people. Many have acquired language skills; they speak English quite well. They comprehend and understand when we talk about the forces of market economy and their implications on pricing etc.

Otherwise the differences one encounters are largely personal. There are people you trust more and those you trust less. I see the difference between the old generation and the new generation as the most significant. It will take, I think, yet another generation when all Russians have adopted the new way of thinking, i.e. the Western thinking. “

Yet another quotation is offered here to illustrate the attitude of Finnish managers to their Russian business partners:

„Basically, I regard them as responsible, but due to external circumstances they cannot quite fulfil their responsibility. Truly, there are irresponsible business people, too. “

\subsection{Towards better understanding}

Personal relations are very important in dealing with Russian business people. The Finns are said to have a competitive advantage over competitors in this respect. During the long years of bilateral trade, delegations of Finnish business people and government officials as well as politicians visited Moscow, Kiev or Alma-Ata on a regular basis, and vice versa.

In most cases, these old business relations have been broken since the bilateral system was abolished. The first task for a business person entering the Russian market is to win the confidence of the Russian partner. As one interviewee explains:

„There are certain rules in business, the first being honesty. When you play with these rules on both sides, with open cards, and trying to give what you can, the other party mutually does the same"

\subsection{Crime issues in Russian-Finnish business relations}

When talking about business ethics, we cannot escape the question of crime. Too many examples have already shown that business operations are not always safe. Surprisingly, the managers interviewed regard the significance of crime as a minimal factor in business relations and operations in Russia. The media tends to exaggerate the situation, they claim.

Whether the Mafia exists in Russia is a question the business managers interviewed found difficulty in answering. Nevertheless, the Mafia is taken as a 
reality and Finnish companies operating in Russia arrange security agreements; they pay for their protection. Low profile and non-advertising are ways in which foreign firms can keep their operations out of the scope of potentially criminal eyes.

\section{Conclusion}

Despite the political insecurity and the great structural problems of a transforming society, Finnish companies are approaching the vast Russian market with high hopes. The interviews showed that Finnish companies perceive themselves as consultants providing know-how in the development of the new business culture in Russia together with an ethical and moral code.

The attitude adopted by the companies interviewed is unquestionably positive. They realise it will take years for the new Russian business culture to develop and to leave the legacy of more than seventy years of communism past behind. The process is more complicated because of the numerous problems related to the transformation.

However, a somewhat patronising attitude can be found among Finnish business managers. It will also take years for the Finnish business partners to get rid of their past, and begin to regard Russian associates truly equal partners. We believe that willingness to learn should be mutual. Western companies should never apply a double standard: one at home, the other in Russia. Successful, long-term, mutually beneficial development depends on that.

\section{References}

Angressano, J. (1992): Comparative Economics. Prentice Hall.

Argandona, A. (1994): Business, law and regulations: ethical issues. In: Harvey, Brian (ed.): Business Ethics. A European Approach. Prentice Hall International (UK) Limited. pp. 124-153.

Blom, A. (1992): Pietarissa on visio. Idankauppa 10.

Bovin, S. (1992): Argumenti i facti 48.

Bridgewater. S. et al. (1993): The Role of Existing Relationships in Western Entry and Expansion Decisions in Ukraine. British Academy of Management Conference. Milton Keynes. September.

Casson, M. (1994): Enterprise Culture and Institutional Change. In: Buckley, P. / Ghauri, P. (eds.): The Economics of Change in East and Central Europe. Academic Press.

Clark, R.W. / Lattal, A.D. (1993): Work place ethics. Littlefield Adams.

Cohen J.R. / Pant, L.W. / Sharp, D.J. (1992): Cultural and socioeconomic constraints on international codes of ethics: lessons from accounting. Journal of Business Ethics 11.

Edwards, V. / Polonsky, G. (1994): Management in Transition. The Conference proceedings of the 6th Conference on Socio-Economics. SASE. Paris. 
Ekonomicke noviny (1992): Ekonomika i Etika Predprinimatilstva. St. Petersburg University of Economics and Finance. Vol. 5.

Erkintalo, H. (1994): Vaatetusteollisuudessa ei viela ostohuumaa, mutta kaannas parempaan. Satakunnan Kansa 16.11.

Etzioni, A. (1991): Eastern Europe: Wealth of Lessons. George Washington University Press.

EVA (1992): Suomi Pietarissa - Pietari Suomessa. Helsinki: Elinkeinoelaman valtuuskunta. EVA-raportti.

Evans, W.A. (1982): Management Ethics: an international perspective. Boston. Nijhoff.

Fey, C. (1994): What makes IJVs successful. The 6th Conference on Socio-Economics. Paris

Forsman, T. (1995): Onko meilla Venajan tuntemusta. Helsingin Sanomat 18.2.

Hãmãlãinen, H. (1993): Johtaja vaikuttaa eettisilla valinnoillaan. Facta 12. pp. 60-61.

Harvey, B. (ed.) (1994.): Business Ethics. A European Approach. Prentice Hall International.

Helsingin Sanomat (1995): Venaja saattaa viela perua matkapuhelimien lupavaatimuksen. 18.2.

Holsti, O. ( 1969): Content Analysis for the Social Sciences and Humanities. AddisonWesley.

Hultin, T. (1995): Tietoa rajan takaa. Kauppakamari 1/95. Tammikuu.

Ivancevich, J.M. / Lorenzi, P. / Skinner, S.J. / Crosby, P.B. (1994): Management: quality and competitiveness. Richard D. Irwin Inc.

Ivanov, A. (1995): Delovoj Mir Rossii. 4/146. Moscow.

Kaplinski, J. (1995): Suomen kulttuuria on omat mallinsa. Helsingin Samnomat 12.2. p. 2.

Kornai, J. (1992): In: Kennet, D. / Lieberman, M. (eds.): The Road to Capitalism. The Dryden Press.

Lapidus, G.W. (1995.): Troubled transformation. The New Russia. Westview Press.

Laurila, J. (1993): Moral Issues in Business - A Study of Top Managers' Perseptions of Morality and Moral Issues in Stakeholder Relations. University of Tampere. School of Business Administration. Part of the licentiate thesis presented at a seminar of KATAJA in Jyvaskyls 16.12. - 17.12.

Liuhto, K. (1991): The Interaction of Managerial Cultures in Soviet-Finnish Joint Ventures. Including Estonian - Finnish Joint Ventures. Institute for East-West Trade. Turku School of Economics and Business Administration. Series B 10.

Liuhto, K. (1993): Tie menestykseen Venajan lahialueilla - Suomalaisten yhteisyritysjohtajien kokemuksia liikkeenjohtamisesta Pietarissa. Petroskoissa ja Murmanskissa. Turku School of Economics and Business Administration. Business Research Center and Institute for East-West Trade. Series B.

Luotonen, J. (1994): Yritysjohtaja tutkii itsean. piispa Raamattua. Talouselama 36/1994. 48.

Miettinen, A. (1994): Liikkeenjohtajien eettiset kasitykset.

Nedela (1995): January 3. 
Niemen, J. (1994): Transition in Eastern Europe - dimensions of transitions, environmental changes and implications for Western managers. Discussion papers C7. Turku School of Economics and Business Administration. Institute for East-West Trade. Turku.

Novacek, K. (1991): Economicke Noviny. 12/5. Bratislava.

Palomaki, T. / Ari P. (1994): Suomalaiset Saksan markkioilla. Suomi-kuvan ja kulttuurierojen heijastumia liiketoiminnassa. Publications of Turku School of Economics and Business Administration. Series C-2.

Pratt, C.B. (1991): Multinational corporate social policy process for ethical responsibility in Sub-Saharan Africa. Journal of Business Ethics 10.

Sachs, J. (1994): Rynochnaja Ekonomika i Rossija. Moscow. Russia.

Satakunnan Kansa (1994): Harjavaltalainen yrittaja: Baltian Maksuliikenne ja Suomen tasolla. 17.12.

Satakunnan Kansa (1994): Ilmastointilaittesta idea puunkuivauslaitteeseen. 17.12.

Satakunnan Kansa (1994): Vaatetusteollisuudessa ei viela ostohuumaa. mutta kaannos parempaan. 16.12.

Sinclair, A. (1993): Approaches to organisational culture and ethics. Journal of Business Ethics 12.

Sokolova, I. (1994): St. Petersburg novosti. 12/9 St.Petersburg.

van Luijk, H. (1994): Business ethics: the field and its importance. In Harvey, B. (ed.): Business Ethics. A European Approach. Prentice Hall International Limited. pp. 1231.

Varila, K. (1992): Basaaritalous tai Pietari Suuren eurooppalainen hovi. Idankauppa 12.

Vitell, S.J. / Nwachukwu, S.L. / Barnes, J.H. (1993): The Effects of Culture on Ethical Decision-Making: An Application of Hofstede's Typology. Journal of Business Ethics 12. 